\title{
Molecular adaptation and expression evolution following duplication of genes for organellar ribosomal protein $\mathrm{SI} 3$ in rosids Shao-Lun Liu and Keith Adams*
}

Address: UBC Botanical Garden \& Centre for Plant Research and Botany Department, University of British Columbia, Vancouver, BC, V6T1Z4, Canada

Email: Shao-Lun Liu - shaolun@interchange.ubc.ca; Keith Adams* - keitha@interchange.ubc.ca

* Corresponding author

Published: 26 January 2008

BMC Evolutionary Biology 2008, 8:25 doi:10.1 186//47|-2/48-8-25

This article is available from: http://www.biomedcentral.com/I47I-2/48/8/25

(C) 2008 Liu and Adams; licensee BioMed Central Ltd.

This is an Open Access article distributed under the terms of the Creative Commons Attribution License (http://creativecommons.org/licenses/by/2.0), which permits unrestricted use, distribution, and reproduction in any medium, provided the original work is properly cited.
Received: 7 August 2007

Accepted: 26 January 2008

\begin{abstract}
Background: Gene duplication has been a fundamental process in the evolution of eukaryotic genomes. After duplication one copy (or both) can undergo divergence in sequence, expression pattern, and function. Two divergent copies of the ribosomal protein S/3 gene (rps/3) of chloroplast origin are found in the nucleus of the rosids Arabidopsis, Gossypium, and Glycine. One encodes chloroplast-imported RPSI3 (nucp rps/3), while the other encodes mitochondriaimported RPSI 3 (numit rps/3). The rps/3 gene has been lost from mitochondrial DNA ( $\mathrm{mt} \mathrm{rps} / 3$ ) of many rosids.

Results: We studied sequence evolution of numit $r p s / 3$ in comparison with nucp $r p s / 3$ in seven rosid genera. $K_{a} / K_{s}$ analysis and likelihood ratio tests showed considerably higher $K_{a}$ values and $K_{a} /$ $\mathrm{K}_{\mathrm{s}}$ ratios in numit $r p s / 3$ than in nucp $r p s / 3$, indicating increased amino acid sequence divergence in numit rps/3. Two positively selected codons were detected in numit RPSI 3 in regions that are inferred to interact with the $16 \mathrm{~S}$ rRNA. Several amino acids in numit RPSI 3 have changed from the one present in nucp RPSI 3 to the one present in $\mathrm{mt}$ RPS 13 , showing that numit $r p s / 3$ is becoming more like $\mathrm{mt} r p s / 3$. Comparison of expression patterns and levels of numit $r p s / 3$ and nucp $r p s / 3$ in Arabidopsis using microarray data indicated divergence in gene expression. We discovered that in addition to numit $r p s / 3$, Malus (apple) contains a transcribed $\mathrm{mt} \mathrm{rps} / 3$ gene. To determine if partitioning of expression takes place between numit $r p s / 3$ and $\mathrm{mt} r p s / 3$, expression of both copies and RNA editing of $\mathrm{mt}$ rps $/ 3$ were examined by RT-PCR, qRT-PCR, and sequencing from 14 different organ types plus seedlings subjected to five different abiotic stresses. Co-expression of numit $\mathrm{rps} / 3$ and $\mathrm{mt} r p s / 3$ was observed in all the organs and various stress treatments. We determined that purifying selection is acting on both numit $r p s / 3$ and $\mathrm{mt} r p s / 3$ in Malus.
\end{abstract}

Conclusion: Our data provide evidence that numit $r p s / 3$ genes in rosids have experienced adaptive sequence evolution and convergent evolution with $\mathrm{mt} r p s / 3$. Co-expression of numit $r p s / 3$ and $\mathrm{mt} r p s / 3$ and purifying selection on both genes in Malus suggest that both are functional. The three organellar $r p s / 3$ genes in rosids provide a distinctive case of gene duplication involving the co-evolution of the nuclear and cytoplasmic genomes. 


\section{Background}

Gene duplication has been an ongoing process during eukaryotic evolution that has provided genetic raw material for the evolution of new gene functions that can lead to morphological and physiological novelty. Duplicated genes can undergo sequence divergence caused by positive selection or neutral drift [1-3] and divergence in expression patterns and function. Two common fates of retained duplicated genes are neofunctionalization - gain of a new function or expression pattern by one copy [4] and subfunctionalization - partitioning of ancestral function or expression pattern between both copies $[5,6]$. Plant genomes contain large numbers of duplicated genes, derived by polyploidy, segmental duplications, tandem duplications, and retroposition of cDNAs. Many duplicated genes in plant genomes have been preserved and undergone purifying selection, a few have undergone positive selection and functional diversification, and some have experienced subfunctionalization [7-10].

There are three genes that code for organellar ribosomal S13 genes among rosid species. Analysis of $r p s 13$ genes in the rosid species Arabidopsis thaliana, cotton (Gossypium arboreum), and soybean (Glycine max) revealed the presence of two expressed copies of $r p s 13$ in the nucleus that were derived by gene duplication $[11,12]$. Both in vitro and in vivo RPS13 protein import experiments indicated that one copy encodes the chloroplast-imported protein (nucp rps13) while the other encodes mitochondriaimported RPS13 (numit rps13) [11,12]. It was inferred that the missing mt $r p s 13$ gene product has been functionally replaced by the product of numit $r p s 13$ in a common ancestor of Arabidopsis, cotton, and legumes. Thus the function of numit $r p s 13$ has been modified after gene duplication, and one could argue that numit rps13 has gained a new function because it is operating in a new cellular context (the mitochondrial ribosome instead of the chloroplast ribosome). Subsequently $\mathrm{mt}$ rps13 was lost from mitochondrial DNA many times during the evolutionary history of rosids, as inferred from a Southern blot hybridization survey [13](see Additional File 1). Surprisingly, however, there were many species of rosids that do appear to retain rps13 in the mitochondrion, based on Southern blot hybridizations, but the gene in some species may not be intact or functional.

The organellar $r p s 13$ genes in rosids provide an intriguing system to study gene duplication because the subcellular location and site of action of numit RPS13 has changed after gene duplication from the chloroplast to the mitochondrion. We have studied sequence evolution of numit rps13 among rosids to determine what kinds of amino acid changes have taken place and where those amino acids are located in the tertiary structure, as well as to test the hypothesis that there has been adaptive evolution.
Also we have examined the divergence of expression patterns between numit rps13 and nucp rps13. After finding intact and expressed numit $r p s 13$ and $\mathrm{mt} r p s 13$ genes in Malus we tested the hypothesis that there has been expression partitioning of the two genes in different organ types and/or stress conditions to preserve both genes.

\section{Results \\ Identification of numit rps I 3 in Malus, Populus, and Citrus and phylogenetic analysis}

To study the evolution of numit rps13 sequences in the rosids, we identified sequences homologous to numit rps13 in Malus, Populus, and Citrus by BLAST searches of the NCBI expressed sequence tag (EST) database using the numit rps 13 from Arabidopsis as a query. ESTs (see Materials and Methods) were aligned and the open reading frames were identified. The genes in each species are predicted with high probability to encode mitochondrial proteins by four prediction programs: MitoProt [14], TargetP v1.1 [15], Predotar v1.03 [16], and iPSORT [17]. Three of the four programs discriminate mitochondrial from chloroplast proteins and no support was obtained for chloroplast targeting. Alignment of the $\mathrm{N}$-termini with mitochondrial targeting presequences from numit $r p s 13$ in other rosid species shows sequence conservation and indicates that they are homologous genes (Figure 1). Because numit rps13 in Arabidopsis, Gossypium, and Glycine have been experimentally shown to be imported into mitochondria but not chloroplasts (Adams et al., 2002), we infer that the products from the homologous genes in Malus, Populus, and Citrus also are targeted to mitochondria. We found numit rps13 sequences only in species belonging to the rosid lineage, suggesting that the gene duplication event that created numit $r p s 13$ likely occurred after the emergence of the rosid lineage. We did not find a numit $r p s 13$ sequence in Vitis, a group at the base of rosids $[18,19]$, despite the mostly sequenced genome [20] and a large EST collection available at NCBI. We infer that the gene duplication event occurred at the base of the eurosids after separation from the Vitaceae lineage (see Additional File 1).

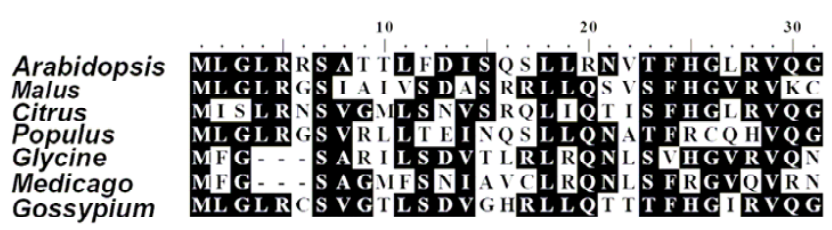

\section{Figure I}

Mitochondrial targeting sequence alignment of numit RPS I3. Predicted targeting presequences of numit RPS I 3 from seven rosid species are aligned. Identical amino acid residues are marked in white on the black background. Dots indicate gaps inserted to improve the alignment. 
Nucp rps13 sequences from seven rosid species were obtained from GenBank by BLAST searches using the previously characterized nucp rps13 from Arabidopsis [21] and aligned with the numit rps13 sequences. Phylogenetic analysis of the sequences verified the orthologous relationships of numit rps13 and nucp rps13 sequences (Figure 2). The phylogenetic relationships inferred from nucp rps13 and numit rps13, however, did not follow established relationships of rosid species [18]. For numit $r p s 13$, the positions of Populus and Gossypium in the tree are switched; for nucp rps13 the gene positions in the tree are completely scrambled. The lack of congruence between the gene trees and organismal phylogeny is probably due to the short sequences being analyzed (about $242 \mathrm{bp}$ after excluding the third codon position). Alternatively, it might be caused by the complex history of multiple polyploidy events and subsequent loss of duplicated genes during rosid evolution. For example, after polyploidization the lineage containing legumes and Malus might have retained copy 1 while Arabidopsis, Citrus, Gossypium and Populus retained copy 2 (Figure 2). Comparisons of branch lengths showed that numit rps13 sequences have diverged rapidly with much longer branch lengths than the nucp rps13 sequences, suggesting there has been accelerated evolution of numit $r p s 13$ in each lineage, and consistent with results from Adams et al. [11] that included fewer species of rosids.

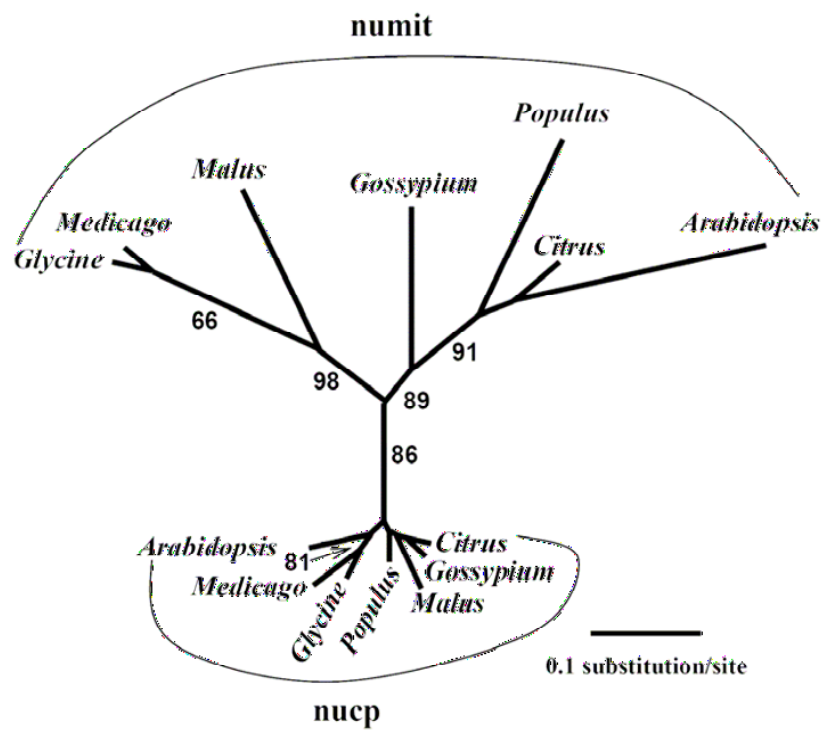

Figure 2

Phylogenetic analysis of numit rps / 3 and nucp $\mathrm{rps} / 3$ from rosid species. Shown is an unrooted phylogram derived from maximum likelihood analyses of the first and second nucleotide positions. Bootstrap values from 100 replicates of $M L$ analyses are labeled on the internodes.

\section{Accelerated nucleotide substitution rates and positive selection on numit rps 13}

To better quantify the rate increase and to determine if both $\mathrm{K}_{\mathrm{a}}$ and $\mathrm{K}_{\mathrm{s}}$ (or just $\mathrm{K}_{\mathrm{a}}$ ) are accelerated in numit rps13 sequences, the $\mathrm{K}_{\mathrm{a}^{\prime}} \mathrm{K}_{\mathrm{s}}$ values, and $\mathrm{K}_{\mathrm{a}} / \mathrm{K}_{\mathrm{s}}$ ratios were compared between nucp rps13 and numit $r p s 13$ in the rosids. Significantly higher $K_{a}$ values and $K_{a} / K_{s}$ ratios were observed in the numit $r p s 13$ genes than in the nucp $r p s 13$ genes $(P<0.05$; Table 1 ; see Additional file 2$)$. The $K_{\mathrm{a}}$ values in the numit $r p s 13$ genes were 3-4 times greater than in the nucp rps13 genes. No significant difference in $\mathrm{K}_{\mathrm{s}} \mathrm{val}$ ues, however, was found between the nucp rps13 and numit $r p s 13$ copies $(P>0.05$; see Additional file 2$)$. These results show that numit rps13 has been experiencing a considerably accelerated rate of non-synonymous substitutions compared with the nucp rps13 in all seven lineages of rosids.

Although simple pair-wise comparison of $\mathrm{K}_{\mathrm{a}}$ and $\mathrm{K}_{\mathrm{s}}$ analysis provides some insights into the accelerated amino acid substitution in numit $r p s 13$, branchwise estimation of $\mathrm{K}_{\mathrm{a}^{\prime}}$ $\mathrm{K}_{\mathrm{s}}$ values, and $\mathrm{K}_{\mathrm{a}} / \mathrm{K}_{\mathrm{s}}$ ratios can provide additional information such as positive selection and adaptive molecular evolution along certain branches and clades [22-26]. To detect if there has been positive selection acting on numit rps13 and nucp rps13 in different rosid species, site specific model analysis was conducted using PAML [23]. (Although synonymous and non-synonymous substitutions are abbreviated as $d_{S}$ and $d_{N}$ in PAML analysis, we use the common designations $\mathrm{K}_{\mathrm{s}}$ and $\mathrm{K}_{\mathrm{a}}$ to refer to synonymous and non-synonymous substitutions, respectively.) Both the rps13 tree (Figure 2) and the species tree that reflects our current understanding of rosid phylogeny [18] were used for detection of positive selection to determine if the tree topology influenced detection of positively selected sites, and no differences were found in this regard.

One ratio model (M0) shows that the $\mathrm{K}_{\mathrm{a}} / \mathrm{K}_{\mathrm{s}}$ ratio of numit rps13 is about 4 times higher than nucp rps13 (Table 2), congruent with observations from simple $\mathrm{K}_{\mathrm{a}}$ and $\mathrm{K}_{\mathrm{s}}$ analysis. For each dataset, likelihood ratio tests (LRT) for detection of positive selection were examined using M7-M8 and M8a-M8 comparisons. For numit $r p s 13, \mathrm{M} 8$ is significantly better than M7 and M8a in numit $r p s 13(P<0.05)$ and $2.3 \%$ of sites are inferred to undergo positive selection (Table 2), suggesting there has been positive selection acting on numit rps13. In addition, based on Bayes Empirical Bayes (BEB) analysis, two codon sites in numit rps13 were identified as showing strong positive selection (posterior probability $>0.8$; Table 2 ). However, there is no evidence for sites under positive selection in nucp rps13. In nucp rps13, M8 is not significantly better than M7 and M8a (Table 2). These results indicate that strong positive 
Table I: Comparison of $\mathrm{K}_{\mathrm{a}} / \mathrm{K}_{\mathrm{s}}$ ratios between nucp $r p s / 3$ and numit $r p s / 3$.

\begin{tabular}{|c|c|c|c|c|c|c|c|}
\hline Taxon & Arabidopsis & Citrus & Glycine & Gossypium & Malus & Medicago & Populus \\
\hline \multicolumn{8}{|c|}{ nucp rps / $3(0.06 \pm 0.02)^{a}$} \\
\hline Arabidopsis & - & & & & & & \\
\hline Citrus & 0.019761 & - & & & & & \\
\hline Glycine & $0.03 \mid 462$ & 0.111523 & - & & & & \\
\hline Gossypium & 0.045554 & 0.051540 & 0.076516 & - & & & \\
\hline Malus & 0.037126 & 0.049357 & 0.081350 & 0.059803 & - & & \\
\hline Medicago & 0.040972 & 0.084293 & 0.059997 & 0.057981 & 0.085442 & - & \\
\hline Populus & 0.048739 & 0.112004 & 0.062117 & 0.049504 & 0.061190 & 0.067945 & - \\
\hline \multicolumn{8}{|c|}{ numit rps / $3(0.28 \pm 0.08)$} \\
\hline Arabidopsis & - & & & & & & \\
\hline Citrus & 0.276419 & - & & & & & \\
\hline Glycine & 0.331700 & 0.253453 & - & & & & \\
\hline Gossypium & 0.257117 & 0.308765 & 0.299647 & - & & & \\
\hline Malus & 0.299325 & 0.317365 & 0.238339 & 0.468253 & - & & \\
\hline Medicago & 0.267372 & 0.179926 & 0.032697 & 0.336763 & 0.273923 & - & \\
\hline Populus & 0.382829 & 0.261000 & 0.241346 & 0.294584 & 0.301918 & 0.170266 & - \\
\hline
\end{tabular}

aThe mean and standard deviation are shown in parentheses.

selection acts on the evolution of numit rps13among the rosid species, particularly at codons 28 and 114 .

\section{Structural location of positively selected amino acids}

Relative locations of the two positively selected sites were plotted on the tertiary amino acid structures of RPS13 from Escherichia coli and Thermus thermophilus (Figure 3) to infer approximate locations in numit RPS13. Except for the C-terminal end which is longer and contains one more $\alpha$-helix structure in T. thermophilus, the overall structure of RPS13 from E. coli and T. thermophilus are relatively similar (Figure 3). RPS13 residues at positions 28 and 114 in E. coli (28 and 116 in T. thermophilus) correspond to the positively selected sites in numit RPS13 based on the amino acid alignment (Figures 3,4). Previous structural and functional studies of Thermus RPS13 showed that there are two structurally important regions where RPS13 interacts with the 16S rRNA [27-29]. One of them is the loop region between helix 1 and turn 1 (residues 22-25) [29]. One of the positively selected residues found in our analysis is close to that region. The second positively selected residue in numit Rps13 is located in the highly basic COOH-terminal extended region (Figure 3). This region is virtually devoid of secondary structure and found to interact with the $16 \mathrm{~S}$ rRNA at the P-site and Asite (residues 116-120 for P-site and residues 120-122 for A-site) [27-29]. Positively selected sites in or near regions that interact with the 16S rRNA suggest that there has been functional refinement of numit RPS13 to interact better with the $16 \mathrm{~S}$ rRNA.

\section{Amino acid changes in numit rps I 3 that increase identity to $\mathrm{mt}$ rps $\mathbf{3}$}

Because numit rps13 was derived from nucp rps13 and encodes a RPS13 protein that functions in the mitochondria, we were interested in determining if the numit RPS13 has become more like the mt RPS13 amino acid sequence. We determined if there have been mutations in the numit rps13 genes in any of the seven rosid species that change an amino acid to the residue that is present in

Table 2: LRT statistics of site specific model for numit rps /3 and nucp rps /3.

\begin{tabular}{|c|c|c|c|c|c|c|c|c|c|c|c|c|}
\hline \multirow[t]{2}{*}{ Gene } & \multirow{2}{*}{$\begin{array}{l}\text { Number of } \\
\text { sequences }\end{array}$} & \multirow[t]{2}{*}{ Tree Lengtha } & \multirow[t]{2}{*}{$\mathrm{K}_{\mathrm{s}}^{\mathrm{a}}$} & \multirow[t]{2}{*}{$\mathrm{K}_{\mathrm{a}}^{\mathrm{a}}$} & \multirow[t]{2}{*}{$\mathrm{K}_{\mathrm{a}} / \mathrm{K}_{\mathrm{s}}^{\mathrm{a}}$} & \multicolumn{2}{|c|}{ I I th class from M8 } & \multicolumn{2}{|c|}{ M7-M8 comparison } & \multicolumn{2}{|c|}{ M8a-M8 comparison } & \multirow{2}{*}{$\begin{array}{l}\text { Selected } \\
\text { positive sites }\end{array}$} \\
\hline & & & & & & $\mathrm{p}, \%$ & $\mathrm{~K}_{\mathrm{a}} / \mathrm{K}_{\mathrm{s}}$ & $2 \delta \mathrm{L}$ & $P$ Value & $2 \delta \mathrm{L}$ & $P$ Value & \\
\hline numit $r p s / 3$ & 7 & 6.93 & 5.35 & 1.30 & 0.24 & 2.7 & 9.7400 & 9.0670 & $0.0107^{b}$ & 7.5048 & 0.0031 & $\begin{array}{l}\text { 28R, II } 14 R \\
(P>0.8)\end{array}$ \\
\hline nucp $r p s / 3$ & 7 & 4.08 & 5.16 & 0.31 & 0.06 & 1.6 & 1.6268 & 4.7952 & 0.0909 & 0.8448 & 0.1790 & None \\
\hline
\end{tabular}

aEstimated using M0 model in PAML.

bBoldface indicates the statistically significant difference $(P<0.05)$. 


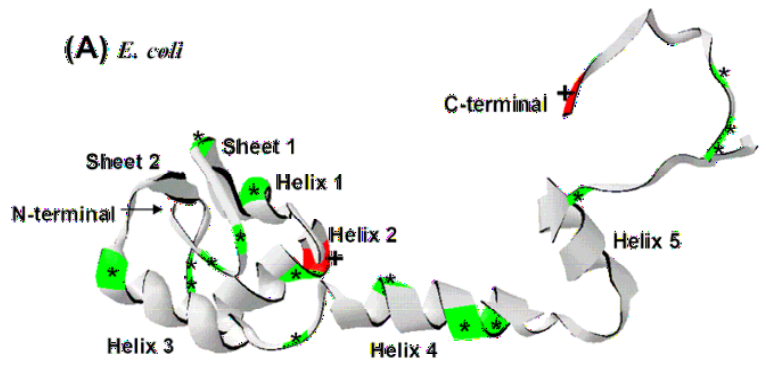

(B) T. thermepthitrs

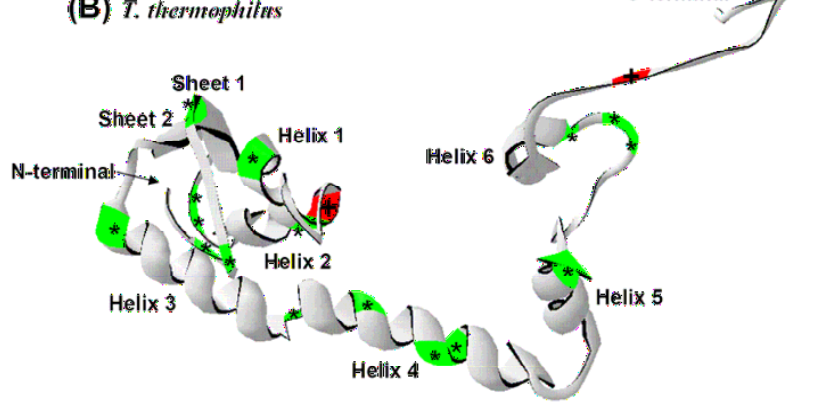

Figure 3

Tertiary structure of numit RPS I3. The structures of RPSI 3 from E. coli (A) and T. thermophilus (B) are shown with amino acids from numit RPSI 3 plotted, as in the alignment (Figure 4). Red regions and plus signs indicate relative positions of positively selected sites. Green regions and asterisks indicate relative positions of amino acids in numit $R p s / 3$ in at least one rosid species that have mutated to the amino acid present in $\mathrm{mt}$ rps $/ 3$ genes (Figure 4). Among them, sites 4 and 10 (Figure 4) are located in the coil region of the $\mathrm{N}$-terminal end, site 15 is in the beginning of the first $\beta$-sheet, site 21 is in the first $\alpha$-helix, site 32 is in the second $\alpha$-helix, sites 42 and 43 are in the coil region between the second $\alpha$-helix and the second $\beta$-sheet, site 53 are in the third $\alpha$-helix, site 67 is in the coil region between the third $\alpha$-helix and the fourth $\alpha$-helix, sites 74,79 , and 80 are in the fourth $\alpha$-helix, and sites $97,107,108$, and I 10 are in the C-terminal coil region.

mt RPS13. In our alignment of nucp RPS13, numit RPS13, and mt RPS13 across different plant species, sixteen sites were identified where numit RPS13 in one or more species has the same amino acid at the corresponding site in mt RPS13 from seven angiosperms, and the amino acid is different from the amino acid(s) present in nucp RPS13 (Figure 4A). The sixteen sites are relatively evenly distributed in the RPS13 tertiary structure (Figure 3). Although little is known about the exact functions of those regions, some of the mutations might help improve the function of numit RPS13 in the mitochondrial ribosome. We plotted the sixteen amino acid changes on the phylogeny of the seven rosid species to infer when they might have occurred (Figure 4B). Mutations are inferred to have occurred along most of the branches, suggesting continuous refinement of the numit rps13 sequence. We infer that three mutations occurred in the common ancestor of all the species, with a subsequent mutation at site 80 in Arabidopsis from $\mathrm{D}$ to $\mathrm{E}$ (a conservative substitution) and at site 110 in Gossypium from A to S, although scenarios with multiple recent mutations cannot be ruled out.

\section{Expression evolution of numit rps I 3}

Having studied sequence evolution of numit rps13 we next tested the hypothesis that there have been changes in expression patterns and levels of expression of numit rps13 relative to nucp rps13. Extensive microarray data are available for Arabidopsis thaliana including a single study that examined expression in 51 organs and developmental stages using the ATH1 array [30]. We analyzed expression data for numit rps13 and nucp rps13 using an ANOVA approach (see Methods). Nucp rps13 is expressed a higher level than numit rps13 in most organs $(P<0.05$; Figure $5 \mathrm{~A}$; Additional file 3$)$. Notable exceptions were roots, senescing leaves and pollen where numit rps13 is more highly expressed $(P<0.05$; Figure 5A). When comparing expression levels of the two genes among organs, sometimes the levels of both genes go up or down together, but sometimes the levels go in opposite directions. Overall the organ-specific expression patterns between the two genes show both similarities and differences $(\mathrm{R}=0.31, P$ $<0.05)$, depending on the organs compared.

To compare expression patterns of numit rps13 to other nuclear encoded ribosomal protein genes, we analyzed expression data for three other nuclear encoded mitochondrial ribosomal protein genes: rps9, rps10, and $r p s 11$ [31]. The expression levels and patterns of all four genes were highly similar $(\mathrm{R}=0.73-0.94, P<0.0001)$, although rps11 expression levels were lower in some organs $(P<$ 0.05 ; Figure 5B). Thus numit rps13 has evolved an expression pattern similar to that of other nuclear-encoded genes for mitochondrial ribosomal proteins, and its expression has diverged from that of nucp rps13.

\section{Malus contains an expressed and RNA-edited copy of rps 13 in the mitochondrion}

Having studied the sequence and expression evolution of numit $r p s 13$ we next consider the fate of $\mathrm{mt}$ rps13 in rosids. A large number of rosids, including Arabidopsis, Gossypium, Glycine, and Citrus have lost mt rps13, as judged by DNA gel blot hybridization [13] (see Additional file 1), but some rosids retain rps13 in mitochondrial DNA. We identified a transcribed copy of rps13 in Malus domestica (apple) from BLAST searches of the NCBI EST database that is $90-92 \%$ identical with the rps13 gene in the mitochondrion of several eudicots. The sequence was derived from a study of ESTs in Malus [32]. A similar gene (97\% 


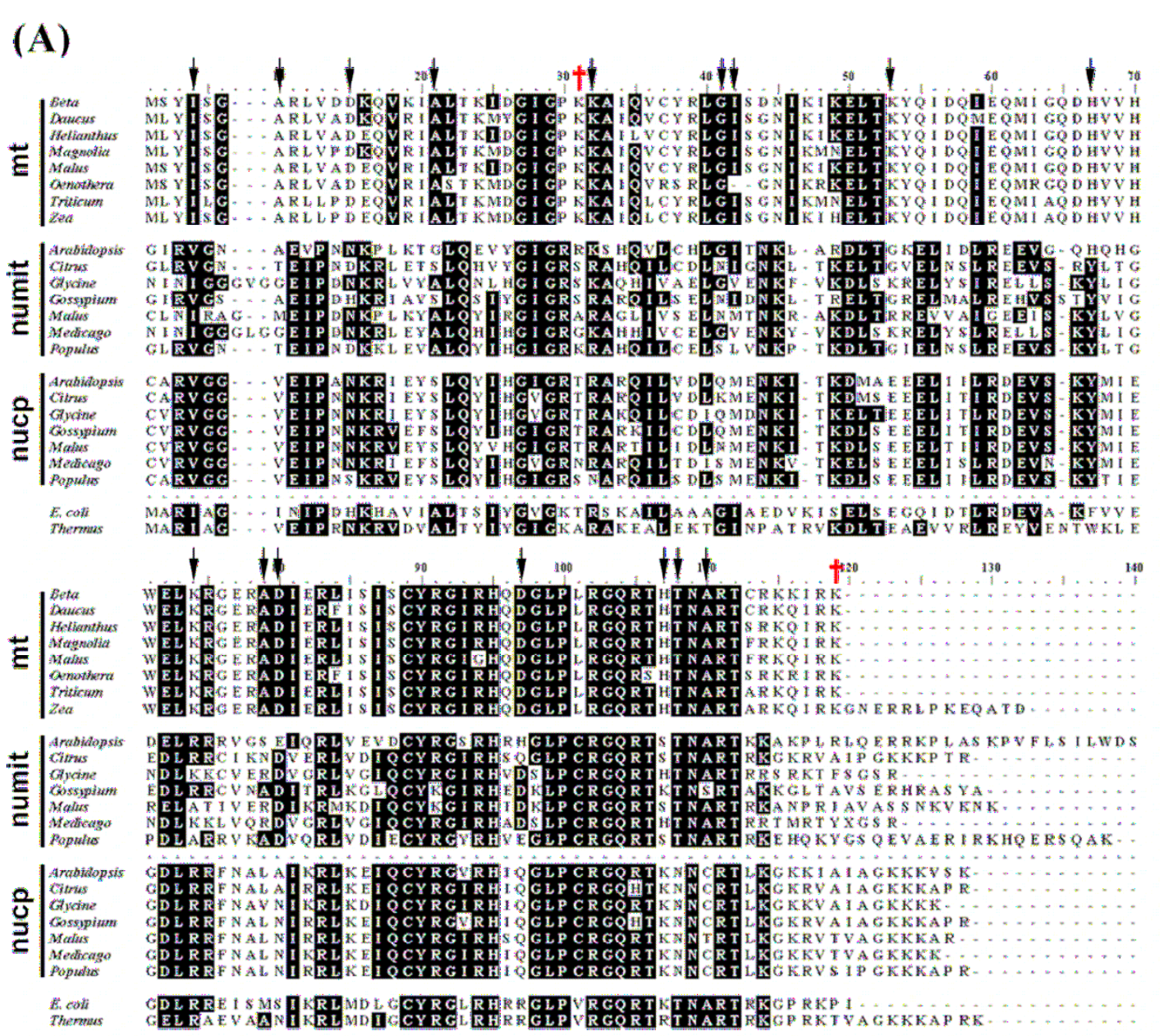

(B)
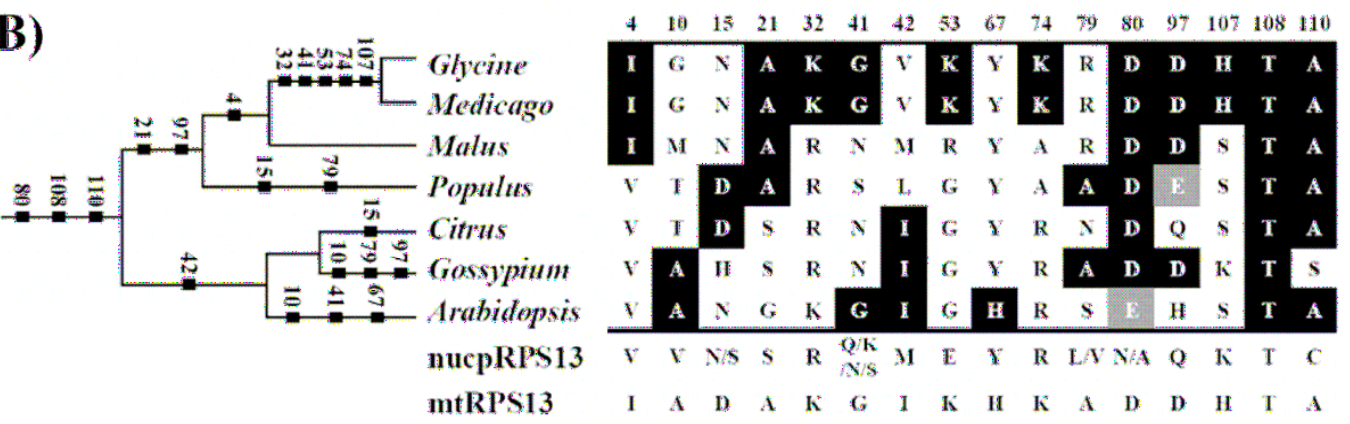

Figure 4

Amino acid evolution in numit RPS I3. (A) Alignment of mt RPSI3, numit RPSI3, nucp RPSI 3 sequences, and RPSI 3 from E. coli and Thermus thermophilis. Amino acids in numit RPSI 3 that are identical to those in mt RPSI 3 or nucp RPSI 3 are shown on a black background. Dashes indicate gaps inserted to improve alignment. Red plus signs indicate positions of positively selected amino acids. Black arrows indicate amino acids in numit rps / 3 in at least one rosid species that have mutated to the amino acid present in all eight $\mathrm{mt}$ rps $/ 3$ genes, summarized in panel B. Panel B also includes a phylogeny of the rosid species and our hypothesized evolutionary timing of each amino acid change. Numbers in panel $B$ indicate positions in the alignment shown in panel $\mathrm{A}$. 
(A)
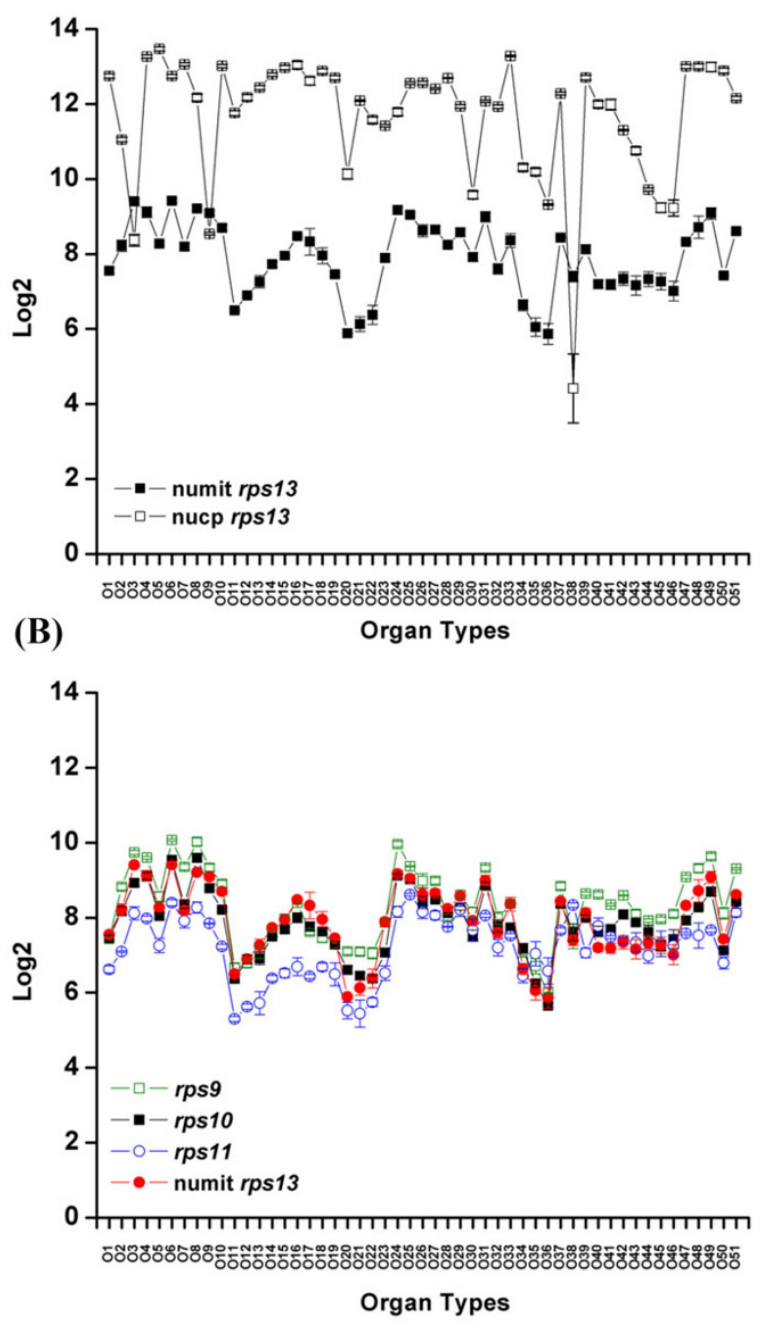

Figure 5

Expression patterns of numit rps / 3 in Arabidopsis thaliana. Shown are graphs from ANOVA analysis of microarray data from $5 \mathrm{I}$ organs and developmental stages (see Methods). Organ types and developmental stages are listed in Additional File 3. Error bars show 3 biological replicates. The $\mathrm{Y}$-axis indicates the expression level normalized by log2. (A) Numit rps/3 compared with nucp rps/3. (B) Numit rps /3 compared with three other nuclear-encoded mitochondrial ribosomal protein genes, rps9, rps /0, and rps/I [3I].

identical) was found in Prunus persica, another member of the Rosaceae family. We evaluated the rps13 sequence from Malus for sites of C-to-U RNA editing by PCR amplifying and sequencing rps13 from genomic DNA and comparing the gDNA sequence to the EST sequences. C-to-U RNA editing plays an important role in the expression of plant mitochondrial genes to restore certain amino acids to those that are evolutionarily conserved [33]. Among angiosperm rps13 genes, nine possible edited sites have been identified (see Additional file 4). Four of those sites are already T's instead of C's in the genomic DNA sequence of mt rps13 from Malus, and thus RNA editing might be expected at five sites in the Malus cDNAs. No editing was observed in the two ESTs from Malus, and the EST from Prunus had editing at only one site (the 100th base). To verify the lack of RNA editing, we amplified and directly sequenced mt rps13 cDNAs from leaves and petals of Malus. Unexpectedly five RNA editing sites were discovered in both leaves and petals at five sites (see Additional file 4). After transcription, RNA editing converts codons from serine to leucine (the 26th, 56th, and 287th bases) and from arginine to cysteine (the 100th and 256th bases). The changes made by RNA editing would restore an evolutionarily conserved amino acid sequence and make the resulting protein likely to be functional, should the transcripts be translated.

\section{Co-expression of numit rps I 3 and $\mathrm{mt}$ rps $\mathrm{I} 3$ in 14 different organ types and under five different stress conditions}

We conducted expression assays of numit rps13 and mt rps13, and RNA editing examination of $\mathrm{mt}$ rps13, in Malus to test the hypothesis that expression patterns have been partitioned between the two genes in different organ types. RT-PCR was performed with (RT+) or without (RT-) reverse transcriptase to check for DNA contamination (Figure 6). Transcripts of numit rps13 and mt rps13 were observed in roots (from seedlings), stems, stigmas + styles, and ovaries. Transcripts of these two genes were also observed in 10 additional organ types: hypocotyls, cotyledons, young leaves (from seedlings), mature leaves, peduncles, petals, seeds, sepals, stamens, and young fruit. Mt rps13 cDNAs were sequenced from each organ type to determine if any sites were edited. Different organ types in apple all showed the five RNA editing sites mentioned above. The results of the RT-PCR experiments show that both copies are co-expressed in all examined organ types.

Although both copies of rps13 are expressed in many organ types it is possible that there might be partitioning of expression between the two genes under stress conditions. We tested the hypothesis by examining the expression patterns of numit rps13 and mt rps13 under five different stresses including cold, dark, heat, salt, and water submersion treatments to determine if expression partitioning occurs under different environmental stresses. Apple seedlings were independently subjected to each of these five stresses (see Materials and Methods). Four organ types, including roots, hypocotyls, cotyledons, and leaves were examined for expression of numit rps13 and mt rps13. Based on RT-PCR results, transcripts of numit rps13 and mt rps13 were observed under each of the five stress conditions: cold, dark, heat, salt, and water submer- 


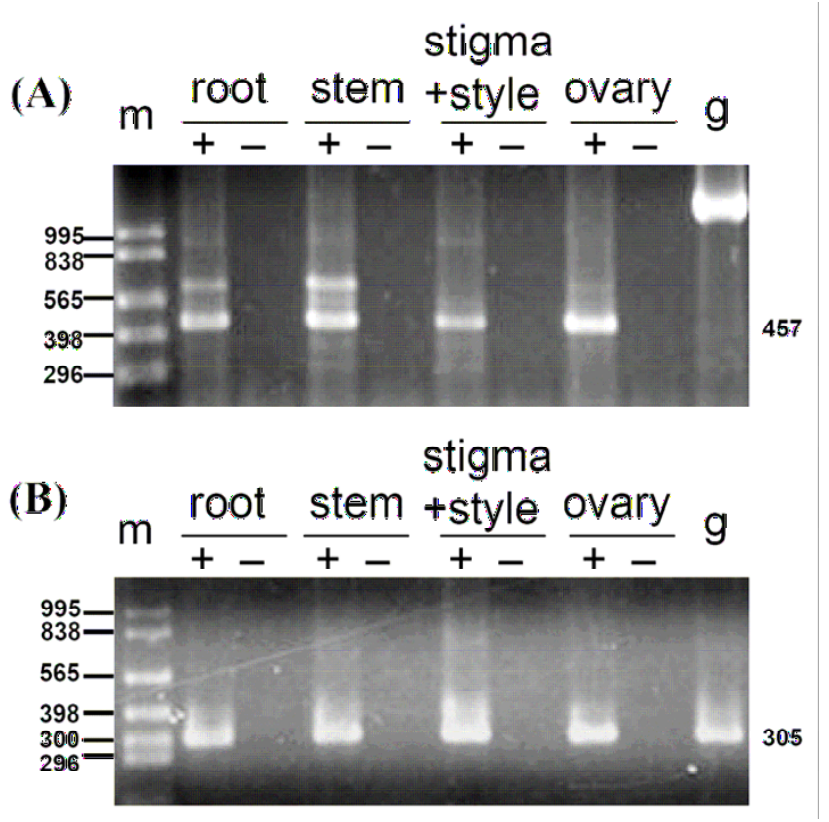

Figure 6

Expression of numit rps / 3 and $\mathrm{mt}$ rps / 3 from in Malus in different organ types. Plus signs indicate reactions containing reverse transcriptase (RT) and minus signs indicate reactions without $R T$. Abbreviations: coty, cotyledon; g, genomic; hypo, hypocotyl; m, marker. (A) A gel showing a subset of the RT-PCR products of numit rps / 3 (457 bp).

Sequencing of a larger band in RT-PCR assays of numit rps / 3 revealed that it was due to non-specific primer binding, whereas the smaller band was the numit rps/3. (B) A gel showing a subset of the RT-PCR products of $\mathrm{mt}$ rps / 3 (305 bp).

sion treatments. Sequencing of RT-PCR products showed that the transcripts were RNA edited at 5 sites, although in some cases there was partial editing at one or more sites.

We have shown transcription of both numit rps13 and $\mathrm{mt}$ rps13 in many organs and under several stress conditions. However it is possible that transcripts from one gene might be present at low levels. PCR of cDNA template (RT-PCR) is not a quantitative technique and low levels of transcripts might not be distinguishable from high levels. To determine if abundant levels of steady-state transcripts are derived from both genes, we used real-time PCR (qRTPCR) to assay transcript levels of numit rps13 and $\mathrm{mt}$ rps13. We compared levels of numit rps13 to those of another nuclear gene for a mitochondrial ribosomal protein, rps10 (for ribosomal protein S10), and we compared levels of mt rps13 to those of another mitochondrial gene, $c o b$ (for cytochrome b). We assayed expression levels in a subset of 9 organs and two stress conditions that were assayed above. Numit rps13 transcripts were present at or above the levels of rps10 in ovaries and roots, and most organs showed at least half as many transcripts from numit rps13 as rps10 (Figure 7A). Cold stress was an exception, where the numit $r p s 13 / r p s 10$ ratios were less than 0.4 (Figure 7A). Mt rps13 transcripts were present at slightly over twice the levels of $c o b$ transcripts in leaves (Figure 7B). The $\mathrm{mt} r p s 13 / \mathrm{cob}$ transcript ratio was above 0.5 in most other organs and under cold stress. Overall there is evidence for relatively high levels of steady-state transcripts from numit rps13 and mt rps13 in most organs.

(A)
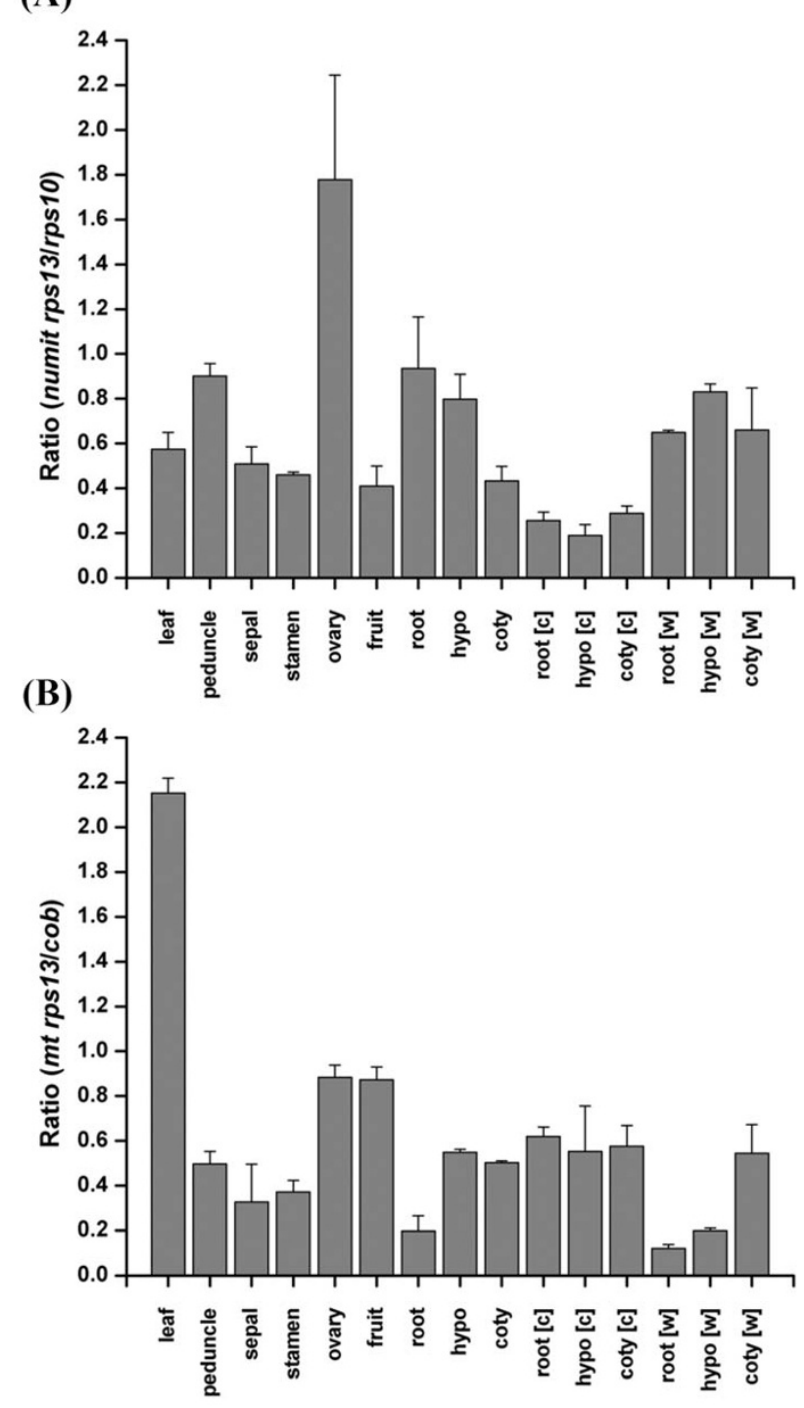

Figure 7

qRT-PCR of numit rps / 3 and $\mathrm{mt}$ rps / 3 in Malus. (A) Ratios of numit rps I 3 to rps 10 transcripts. (B) Ratios of $\mathrm{mt}$ rps I 3 to cob transcripts. Error bars show variation from two replicates. 


\section{Purifying selection acting on numit rps I 3, nucp rps I 3, and mt rps 13 in Malus}

Detecting purifying selection, neutral evolution, and positive selection on each of the three rps13 genes would provide insights into the selective forces at work and could indicate if one copy is a pseudogene. $A K_{a} / K_{s}$ ratio less than one would indicate purifying selection and be evidence for a functional gene, and a $\mathrm{K}_{\mathrm{a}} / \mathrm{K}_{\mathrm{s}}$ ratio of about one would be evidence of neutral evolution and thus probably pseudogenization. The branch specific model in PAML was used to detect adaptive molecular evolution in numit rps13, nucp rps13, and $\mathrm{mt} r p s 13$ for the Malus branches by comparing with other plant species. For each LRT, M1 is the model assuming neutral evolution among sites, $\mathrm{MA}_{\text {test } 1}$ assumes that there are positively selected amino acid sites for the foreground lineage, and $\mathrm{MA}_{\text {test2 }}$, is used to test if the detection of positive selection is an artifact. LRTs showed that $\mathrm{MA}_{\text {test } 1}$ is not significantly better than $\mathrm{M} 1$ and $\mathrm{MA}_{\text {test2 }}$ in Malus numit rps13 and Malus $\mathrm{mt} r p s 13$, indicating that there is no positive selection for these two branches (Table 3 ). For nucp rps13, $\mathrm{MA}_{\text {test1 }}$ is significantly better than $M 1$, but not better than $\mathrm{MA}_{\text {test2 }}$ (Table 3), suggesting that there is no positive selection in nucp rps13. In addition, branch specific models can provide detailed information about how many sites are undergoing purifying selection, neutral evolution, and positive selection. For numit $r p s 13,65 \%$ of the sites are under purifying selection with $\mathrm{K}_{\mathrm{a}} / \mathrm{K}_{\mathrm{s}}$ less than one, $28 \%$ of sites are under neutral evolution with $\mathrm{K}_{\mathrm{a}} / \mathrm{K}_{\mathrm{s}}$ close to one, and $7 \%$ of sites are under positive selection with $\mathrm{K}_{\mathrm{a}} / \mathrm{K}_{\mathrm{s}}$ greater than one (Table 3) without statistical support by LRTs. For nucp rps $13,90 \%$ of sites are under purifying selection, $7 \%$ of sites are under neutral selection, and 3\% of sites are under positive selection (Table 3) although the positively selected sites are not supported by LRTs. For mt $r p s 13$, $66 \%$ of sites are under purifying selection and $34 \%$ of sites are under neutral selection (Table 3 ). The number of sites experiencing each type of selection in numit rps13 in Malus is similar to numit rps 13 in other rosids that do not have mt rps13 (Table 4). Overall our results reveal that the three ribosomal protein S13 genes in Malus are undergoing higher purifying selection than neutral evolution, sug- gesting that their functionality is maintained by purifying selection.

\section{Discussion \\ Continuous accelerated evolution and molecular adaptation of numit rps 13 among rosids}

After gene duplication some retained duplicated genes undergo asymmetric rate divergence and the faster evolving copy experiences relaxed constraint or positive selection $[34,35]$. The increased $K_{a}$ rate, $K_{a} / K_{s}$ ratio, and positively selected sites detected in numit rps13, compared with nucp rps13, across different rosid species show there has been accelerated sequence evolution of numit rps13. The increased $\mathrm{K}_{\mathrm{a}}$ rate is likely to be correlated with the modified function of numit $r p s 13$ - from encoding a chloroplast ribosomal protein to a mitochondrial ribosomal protein. Some amino acid sequence changes were probably necessary for numit RPS13 to interact well with other proteins in the mitochondrial ribosome. The increased rate of non-synonymous substitutions is a continuing process instead of there being a burst of sequence change upon formation of numit $r p s 13$ followed by a prolonged period of lower rates of non-synonymous substitutions. The continued higher $K_{a}$ rate, and the two positively selected codons in numit rps13 near the positions where RPS13 interacts with 16S RNA domain, show that the sequence, and suggest that the function, of numit RPS13 in mitochondria is continuing to be refined. Site-specific positive selection has been detected in other duplicated genes [36-38]. For example, in duplicated AP3 and PI genes there has been functional diversification driven by positive selection acting on different sites within a functional domain involved in heterodimerization [39].

The sixteen amino acids in one or more rosid species that have changed to the amino acid present in $\mathrm{mt}$ RPS13 (Figure 4) indicate that numit RPS13 is becoming more like $\mathrm{mt}$ RPS13. We propose that this is a type of convergent sequence evolution of numit $r p s 13$ that possibly improves the function of numit RPS13 in the ribosome. The amino acid changes appear to have been taking place continuously during rosid evolution (Figure 4B), with the largest

Table 3: LRT statistics of branch specific model for Malus branch.

\begin{tabular}{|c|c|c|c|c|c|c|}
\hline \multirow[t]{2}{*}{ Gene } & \multirow[t]{2}{*}{ Parameters from $M A_{\text {test } 1}$} & \multicolumn{2}{|c|}{ MI-MA testl $_{\text {comparison }}$} & \multicolumn{2}{|c|}{$M A_{\text {test2 }}-M A_{\text {testl }}$ comparison } & \multirow[t]{2}{*}{ Selected positive sites } \\
\hline & & $2 \delta \mathrm{L}$ & $P$ Value & $2 \delta \mathrm{L}$ & $P$ Value & \\
\hline numit $r p s / 3$ & $\begin{array}{l}P_{0}=0.6485, P_{1}=0.2817,\left(P_{2}+P_{3}=0.0698\right) \\
\omega_{0}=0.12, \omega_{1}=1, \omega_{2}=112.98\end{array}$ & 1.7396 & 0.4190 & 1.2140 & 0.2705 & $31 \mathrm{H}, 32 \mathrm{Q}, \mathrm{II} \mathrm{R}(0.5<P<0.8)$ \\
\hline nucp rps /3 & $\begin{array}{l}P_{0}=0.9005, P_{1}=0.0733,\left(P_{2}+P_{3}=0.0262\right) \\
\omega_{0}=0.04, \omega_{1}=1, \omega_{2}=96.7\end{array}$ & 9.7274 & $0.0077^{a}$ & 3.5026 & 0.0613 & $32 Q, 105 C$ \\
\hline $\mathrm{mt} r p s / 3$ & $\begin{array}{l}P_{0}=0.6646, P_{1}=0.3354,(p 2+p 3=0) \omega_{0}= \\
0, \omega_{1}=1, \omega_{2}=1\end{array}$ & 0 & I & 0 & 1 & None \\
\hline
\end{tabular}

aBoldface indicates the statistically significant difference $(P<0.05)$. 
Table 4: Selection on numit RPSI 3 in seven rosid species.

\begin{tabular}{|c|c|c|c|c|c|c|c|c|}
\hline \multirow[t]{2}{*}{ Taxon } & \multirow{2}{*}{$\begin{array}{l}\text { Purifying Selection } \\
\qquad\left(\%, \mathrm{~K}_{\mathrm{a}} / \mathrm{K}_{\mathrm{s}}<\mathrm{I}\right)^{\mathrm{a}}\end{array}$} & \multirow{2}{*}{$\begin{array}{l}\text { Neutral Evolution } \\
\left(\%, \mathrm{~K}_{\mathrm{a}} / \mathrm{K}_{\mathrm{s}}=\mathrm{I}\right)^{\mathrm{a}}\end{array}$} & \multirow{2}{*}{$\begin{array}{l}\text { Positive Selection } \\
\left(\%, \mathrm{~K}_{\mathrm{a}} / \mathrm{K}_{\mathrm{s}}>\mathrm{I}\right)^{\mathrm{a}}\end{array}$} & \multicolumn{2}{|c|}{ MI-MA $A_{\text {testl }}$ comparison } & \multicolumn{2}{|c|}{$M A_{\text {test2 }}-M A_{\text {test } 1}$ comparison } & \multirow{2}{*}{$\begin{array}{l}\text { Selected positive } \\
\text { sites }\end{array}$} \\
\hline & & & & $2 \delta \mathrm{L}$ & $P$ Value & $2 \delta \mathrm{L}$ & $P$ Value & \\
\hline Malus & 65 & 28 & $7(120.33)^{b}$ & 1.7396 & 0.4190 & 1.2140 & 0.2705 & $31 \mathrm{H}, 32 \mathrm{Q}, 117 \mathrm{R}$ \\
\hline Citrus & 65 & 30 & $5(154.19)$ & 4.3230 & 0.1152 & 3.9182 & $0.0478^{c}$ & $50 \mathrm{~K}, 92 \mathrm{H}$ \\
\hline Glycine & 67 & 33 & 0 & 0 & I & 0 & 1 & $35 \mathrm{C}$ \\
\hline Medicago & 67 & 33 & 0 & 0 & 1 & 0 & I & None \\
\hline Gossypium & 64 & 36 & 0 & 0.6314 & 0.7293 & 0.0024 & 0.9609 & I08K \\
\hline Populus & 66 & 30 & $4(18.05)$ & 3.6624 & 0.1603 & 3.4746 & 0.0623 & 39I, 88S, I02S \\
\hline Arabidopsis & 52 & 48 & 0 & 6.1770 & 0.0456 & 0 & 1 & $\begin{array}{c}\text { I8G, } 36 \mathrm{H}, 60 \mathrm{G}, \\
83 \mathrm{D}\end{array}$ \\
\hline
\end{tabular}

aEstimated using $M A_{\text {test }}$.

bBracket indicates $\mathrm{K}_{\mathrm{a}} / \mathrm{K}_{\mathrm{s}}$ ratio. If $\mathrm{K}_{\mathrm{a}} / \mathrm{K}_{\mathrm{s}}$ ratio is close to one for the third and fourth class of MA it will be counted into the category of neutral evolution.

'Boldface indicates a statistically significant difference $(P<0.05)$.

number (five) having occurred on the branch leading to the legumes Glycine and Medicago. We speculate that some of the amino acid changes that have taken place along the terminal or subterminal branches of the tree might have allowed numit $r p s 13$ to be selected for, over mt $r p s 13$, and allowed multiple independent losses of $\mathrm{mt}$ rps13 in different lineages (see Additional file 1). In species where $\mathrm{mt}$ $r p s 13$ has been lost the product of numit $r p s 13$ presumably functions as well as, or perhaps better than, mt rps13 or else there would have been selection for retention of $\mathrm{mt}$ rps13. Overall the adaptive and convergent evolutionary forces that seem to be acting on numit rps13 have continued during rosid evolution instead of being factors only soon after gene duplication in a common ancestor of most rosids.

\section{Expression evolution of numit rps 13 and nucp rps 13 in Arabidopsis}

Expression patterns of some duplicated genes have been shown to evolve in a divergent and sometimes asymmetric manner [40-42]. For example, many of the genes derived by an ancient polyploidy event in the Arabidopsis lineage have undergone considerable expression divergence [43-45], some of which may have been asymmetric between the two duplicates. Considering that numit rps13 and nucp rps13 show asymmetric divergence in sequence, and different subcellular locations of their protein products, we predicted that they also would show asymmetric divergence in expression, with the expression pattern of numit rps13 being similar to that of other nuclearencoded genes for mitochondrial ribosomal proteins. Numit $r p s 13$ and nucp rps13 did show some differences in expression patterns although the differences were only dramatic in roots, senescing leaves, and pollen. Numit rps13 has evolved a similar expression pattern to three other genes for mitochondrial ribosomal proteins, per- haps by gaining regulatory elements from another gene for a mitochondrial protein, as have several mitochondrial genes that have been transferred to the nucleus [46]. Alternatively there may have been mutations in the regulatory elements of numit rps13 soon after gene duplication that produced an expression pattern similar to that of other genes for mitochondrial ribosomal proteins. Considering that numit rps13 was formed in a common ancestor of most rosids, distinguishing between the above possibilities about the origin of its regulatory elements is impossible. Overall numit rps13 and nucp rps13 add to the growing number of duplicated genes reported in Arabidopsis thaliana that have experienced divergence in expression patterns.

\section{Co-expression of numit rps 13 and $\mathrm{mt}$ rps $\mathrm{I} 3$ in Malus}

We have shown that numit rps13 and mt rps13 in Malus are both transcribed in 14 different organ types and under five abiotic stress conditions, mt rps13 is RNA edited at sites to make the transcripts contain an evolutionarily conserved sequence, and abundant steady-state transcripts from both genes are present in a variety of organs. Both genes are experiencing purifying selection. Taken together, the data obtained in this study indicate that it is likely that both numit rps13 and mt rps13 in Malus are functional genes and not pseudogenes. However there is the possibility, albeit unlikely, that transcripts from one gene (particularly mt rps13) might not be translated. Even if both proteins are present, there is the possibility that only one is assembled into mitochondrial ribosomes, and that process could vary among organs and environmental conditions. Showing that both numit RPS13 and mt RPS13 proteins are assembled into mitochondrial ribosomes, especially in a variety of organ types and under various environmental conditions, is beyond the scope of the current evolutionary study. 
Although we have provided evidence for the functionality of the gene products from numit rps13 and mt rps13 in Malus, might numit rps13 have experienced functional reversion to encode a chloroplast protein? Several lines of evidence do not support that possibility. The mitochondrial targeting presequence of numit RPS13 is similar to those of numit RPS13 in Arabidopsis, Gossypium, and Glycine (Figure 1), each of which was experimentally determined to be imported into mitochondria but not chloroplasts $[11,12]$. Numit rps13 in Malus does not have a greatly accelerated rate of sequence evolution or show more sites under positive selection, compared with numit rps13 in other rosids, as might be expected if its product now functions in the chloroplast. Instead purifying selection is operating on numit rps13 in Malus. Finally, there is no evidence to suggest that nucp rps13 in Malus is a pseudogene and indeed the gene is experiencing strong purifying selection.

Co-expression of numit $r p s 13$ and $\mathrm{mt} r p s 13$ genes in Malus contrasts with the atp9 genes in Neurospora crassa where the nuclear and mitochondrial copies are expressed during different stages of the life cycle [47] and expression has been partitioned between the two genes. Presumably the nuclear copy of atp9 was derived from transfer of the mitochondrial gene to the nucleus in an ancestor of Neurospora, and the current availability of several ascomycete genome sequences could shed light on the evolutionary timing of the gene transfer. Only three other cases of coexpression of nuclear and mitochondrial genes have been reported, to our knowledge, including cox 2 genes in multiple legume species within the Phaseoleae tribe [48], rpl5 genes in wheat (Triticum aestivum) [49], and sdh4 genes in Populus [50]. Those genes contrast to rps13 in rosids because the nuclear copies were derived by transfer of the mitochondrial gene to the nucleus.

Considering that numit rps13 was created by gene duplication in the common ancestor of most rosids, co-expression of $\mathrm{mt}$ rps13 and numit rps13 in Malus has presumably occurred for a long period of evolutionary time. Other cases of co-expression of nuclear and mitochondrial genes in plants represent evolutionarily recent gene transfers to the nucleus. Indeed following transfer of a mitochondrial gene to the nucleus the mitochondrial copy is often lost in a relatively short amount of time [13]. Thus it was unexpected that numit $r p s 13$ and $\mathrm{mt} r p s 13$ have been preserved without partitioning of expression patterns. Why would both copies continue to be retained and expressed? One possibility is that there is partitioning of expression in organs, tissues, or cell types, or under environmental conditions that were not examined in this study. Another possibility is that, despite the considerable level of sequence divergence between numit rps13 and $\mathrm{mt} r p s 13$ (about $42 \%$ identity), the product of either gene functions well in the mitochondrial ribosomes of Malus. That possibility is supported by the fact that some rosids (such as Arabidopsis, Gossypium, Glycine, and Citrus) have only the numit rps13 and non-rosid angiosperms have only mt rps13. Another possibility is that mutations have not occurred in numit rps13 from Malus that cause it to be selected for over mt $r p s 13$, as presumably occurred in other lineages of rosids that have lost $\mathrm{mt} r p s 13$. In this regard it is notable that there are no amino acid changes in numit RPS13 to the residue present in mt RPS13 that occurred along the terminal branch leading to Malus (Figure 4B), unlike all of the other terminal branches on the tree leading to species that have lost mt rps13.

\section{Conclusion}

The accelerated rate of amino acid evolution, positive selection on specific sites, and amino acid changes to the residue present in $\mathrm{mt}$ RPS13 provide evidence that numit $r p s 13$ genes in rosids have experienced adaptive evolution and convergent sequence evolution with $\mathrm{mt} r p s 13$. Numit rps13 provides an example of a gene that has experienced site-specific positive selection while the gene as a whole has been under purifying selection. Expression patterns of numit $r p s 13$ have diverged to become similar to those of other genes for mitochondrial ribosomal proteins. Malus contains intact genes for both numit $r p s 13$ and mt rps13 that are transcribed in a range of organs and under several abiotic stresses. Abundant levels of steady state transcripts from both numit rps13 and mt rps13 in Malus in a variety of organ types, as well as purifying selection acting on both genes, suggest that both genes are functional and not pseudogenes. The three organellar rps13 genes in rosids provide a distinctive case of gene duplication involving the co-evolution of the nuclear and cytoplasmic genomes.

\section{Methods \\ Database searches}

The following expressed sequence tags (EST) for numit rps13 were obtained from GenBank by BLAST searches using numit rps13 from Arabidopsis thaliana (DR380621) as a query: Citrus sinensis (X672493), Malus domestica (DR995890, CN494589, CN925904, and CX023021), Populus trichocarpa (DT496554), Medicago truncatula (BI272420), Glycine max (BM188020), and Gossypium hirsutum (DW488419). The following ESTs for nucp rps13 were obtained from GenBank by BLAST searches using nucp rps13 from Arabidopsis thaliana (DR367899) as a query: Citrus sinensis (CX053776), Glycine max (EH261685), Gossypium hirsutum (DW226103), Malus domestica (DT000985), Medicago truncatula (BI265445) and Populus trichocarpa (DT486949). Mt rps13 ESTs from

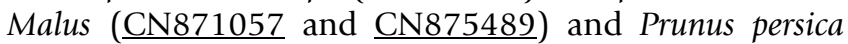
(AJ873687) were identified by BLAST searches of GenBank using mt $r p s 13$ from Beta vulgaris as a query. Mt rps13 genes used in this study include: Triticum aestivum 


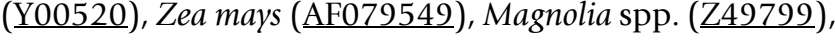

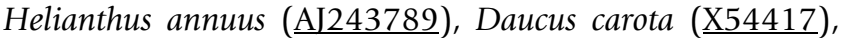
Oenothera berteriana ( $\underline{\mathrm{X} 5416)}$, Beta vulgaris (DQ381464) and Marchantia polymorpha (M68929).

\section{Sequence alignment/analysis and phylogenetic analysis} Sequence alignment was done using transAlign, which aligns protein-coding DNA sequence based on the alignment of amino acids [51]. Aligned sequences were refined with BioEdit [52] for further phylogenetic and codon substitution analysis (see Additional file 5). For phylogenetic analysis, maximum likelihood (ML) analysis was conducted with MultiPhyl v1.0.6 [53] with SPR (subtree pruning and regrafting) branch swapping. The optimal evolutionary model selected for ML was K81uf $+\mathrm{I}+\mathrm{G}$ (Kimura three parameter with unequal base frequencies + proportion of sites + gamma distribution) using the following parameters: assumed nucleotide frequencies $\mathrm{A}=$ $0.36736, \mathrm{C}=0.20950, \mathrm{G}=0.27698, \mathrm{~T}=0.14616$; expected transition/transversion ratio $=0.94$; expected pyrimidine transition/purine transition ratio $=0.30$; proportion sites assumed to be invariable $=0.29$; rates for variable sites assumed to follow the gamma distribution with shape parameter $=4.28$. Bootstrapping was performed using MultiPhyl v1.0.6 with neighbor-joining algorithm and 100 replicates [53].

\section{$K_{a} / K_{s}$ analyses and likelihood ratio tests (LRT) for positive selection}

Nonsynonymous $\left(\mathrm{K}_{\mathrm{a}}\right)$ and synonymous $\left(\mathrm{K}_{\mathrm{s}}\right)$ nucleotide substitution rates were calculated by using program yn00 in PAML v3.15 [23] (see Additional file 2). The $t$-test was used for testing for significant differences of $K_{a^{\prime}} K_{s^{\prime}}$ and $K_{a} /$ $\mathrm{K}_{\mathrm{s}}$ ratios between the nucp rps13 and numit $r p s 13$ cDNA sequences. The statistically significant level was set at $95 \%$. The statistical analysis in this study was implemented by using the statistical package $\mathrm{R}$ [54].

For detection of positive selection, codon-based analysis was implemented using codeml in PAML v3.15 [23]. The mature coding region, without the mitochondrial targeting presequences, was included in our analysis. Site specific models were used for testing positive selection on numit $r p s 13$ and nucp rps13 [25]. Two LRTs were used for the detection of positive selection: M7-M8 and M8a-M8 $[22,25,26]$. Because comparison of $M 7$ and $M 8$ provides a more powerful test of positive selection and has less sensitivity to large evolutionary distances and $\mathrm{G}+\mathrm{C}$ content than comparison of M1 and M2 [55,56], only comparison of $\mathrm{M} 7$ and $\mathrm{M} 8$ was used for the detection of positive selection in this study. M7 and M8a models are the null models without positive selection (no codon with $\mathrm{K}_{\mathrm{a}} / \mathrm{K}_{\mathrm{s}}>1$ ) and the M8 model is the alternative model with positive selection. Branch specific model was used to test if there has been positive selection for Malus branch in numit rps13, nucp rps13, and mt $r p s 13$ [25]. For this analysis, the branch which we are interested in testing positive selection was assigned as foreground lineage. Therefore, Malus branch in numit $r p s 13$, nucp rps13, and mt $r p s 13$ were set as foreground lineage and the rest of other rosid species were designated as background lineage. For branch specific model, two LRTs were used for detection of positive selection as follows: M1-Model A test1 $\left(\mathrm{MA}_{\text {test } 1}\right)$ and Model A test2 $\left(\mathrm{MA}_{\text {test2 }}\right)-\mathrm{MA}_{\text {test1 } 1}[25,26]$. $\mathrm{M} 1$ and $\mathrm{MA}_{\text {test2 }}$ models are the null hypothesis without positive selection (no codon with $\mathrm{K}_{\mathrm{a}} / \mathrm{K}_{\mathrm{s}}>1$ ) and the $\mathrm{MA}_{\text {test } 1}$ model is the alternative selection with positive selection. For site-specific and branch-specific models used for detection of positive selection, $\mathrm{M} 8 \mathrm{a}$ is more stringent than $\mathrm{M} 7$ and $\mathrm{MA}_{\text {test2 }}$ is more stringent than $M 1$ because their $\omega_{2}\left(K_{a} / K_{s}\right)$ is fixed at 1 . For all LRTs, the first model is simpler than the second one, with fewer parameters and poor fit to the data. Therefore, the first model has a lower maximum likelihood index. To test if there is statistically better maximum likelihood for the second model, twice difference of log maximum likelihood values between the two compared models $[2 \delta \mathrm{L}=2(\operatorname{Ln} 2-\operatorname{Ln} 1)$, where $\operatorname{Ln} 1$ and $\operatorname{Ln} 2$ represent for log of maximum likelihood value in the first model and the second model] was compared against $\chi^{2}$ distribution. The degrees of freedom (d.f.) equals to the additional parameters used in more complex model. The d.f.

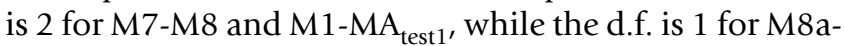
$\mathrm{M} 8$ and $\mathrm{MA}_{\text {test } 2}-\mathrm{MA}_{\text {test } 1}$. However, it was argued that the appropriate model comparison for $\mathrm{M} 8 \mathrm{a}-\mathrm{M} 8$ would be to use 50:50 mixture of d.f. $=0$ and d.f. $=1$ [22]. In this study, the calculation of $P$ value for M8a-M8 was followed as described in Kapralov and Filatov [57]. $P$ value was first obtained using d.f. $=1$ and then divided by 2 . Bayes empirical bayes (BEB) approach was used to determine positive selected sites in $\mathrm{M} 8$ model and $\mathrm{MA}_{\text {test } 1}$ model. In $\mathrm{BEB}$ analysis, the posterior probabilities were calculated to select the codon with $\mathrm{K}_{\mathrm{a}} / \mathrm{K}_{\mathrm{s}}$ greater than 1 . Because BEB analysis is more powerful to detect positive selection than naive empirical Bayes (NEB) analysis [58], only BEB analysis was considered in this study.

\section{Structural analysis of RPS I3}

Using first approach mode in SWISS-MODEL [59], nucp, numit, and mt RPS13 amino acid sequences in Malus were selected to search for a suitable template for further structural analysis. Based on the results, RPS13 of Escherichia coli and Thermus thermophilus were chosen for the following structural analysis. RPS13 structural data file for $E$. coli (PDB ID: 2gy9M) [60] and T. thermophilus (PDB ID: 1fjgM) [27] were obtained from RCSB Protein Data Bank [61]. Location and property of each amino acid in E. coli and T. thermophilus RPS13 was analyzed using DeepViewSwiss-PdbViewer v.3.7 [59]. Selected positive sites obtained by BEB analysis and sites shared with similarity between numit RPS13 and mt RPS13 were plotted in the 
relative position of RPS13 in E. coli and T. thermophilus according to amino acid alignment (Figure 4).

\section{Microarray data analysis}

Raw Affymetrix ATH1 microarray data [30] were downloaded from the TAIR website (TAIR accession number: ME00319)[62]. Raw data were processed and normalized based on the GC-RMA method [63]. The expression values were converted into log2 numbers by only considering values of perfect-match probes [63]. Normalization and analysis of the microarray data were implemented using Bioconductor. Pearson correlation analysis was conducted to statistically compare the similarity of expression profile among rps9, rps10, rps11, and numit rps13, and between numit rps13 and nucp rps13. The correlation coefficient $(\mathrm{R})$ values correspond to the similarity of the expression profile between two genes. A one-way ANOVA with Bonferroni post hoc tests was used to test if there is a significant expression difference between two different genes or any two different organ types. All statistical analyses were implemented using statistical package R [54]. The statistically significant level was set at 95\%.

\section{Plant materials and abiotic stress treatments}

Several organ types, including stems, leaves, peduncles, sepals, petals, stamens, stigmas+styles, and young fruit of apple (Malus domestica Borkh.) were collected from the University of British Columbia's Botanical Garden. Seedlings were used for abiotic stress experiments. Prior to sowing, apple seeds were soaked in distilled water at $4{ }^{\circ} \mathrm{C}$ for 6 weeks for vernalization. Seedlings were cultivated in a peat-vermiculite soil mixture under fixed day/night (16 $\mathrm{h}$ day/ $8 \mathrm{~h}$ night) and temperature of $20-23^{\circ} \mathrm{C}$. After germination and emergence from the soil for 7 days, the plants were subjected to five different abiotic stresses: $4^{\circ} \mathrm{C}$ for 7 days (cold treatment), $37-40^{\circ} \mathrm{C}$ for 12 hours (heat stress), $100 \mathrm{mM} \mathrm{NaCl}$ solution for 7 days (salt treatment), submerged in distilled water for 4 days (water submersion treatment), and dark for 7 days (dark treatment). After stress treatments, roots, hypocotyls, cotyledons, and leaves were collected and immediately frozen in liquid nitrogen and stored at $-80^{\circ} \mathrm{C}$ until nucleic acid extraction.

\section{Nucleic acid extraction, gene amplification, and sequencing}

Genomic DNA extraction was done using the DNeasy Plant Mini Kit (Qiagen) following the manufacturer's protocol. Total RNA extraction was performed as described previously [64]. The extracted nucleic acid concentrations and purities were determined by using a NanoDrop spectrophotometer. The quality was checked by running on $1.5 \%$ agarose gels. Before reverse transcription, $3 \mu \mathrm{g}$ of RNA $(500 \mu \mathrm{g} / \mu \mathrm{l})$ was treated with 1 unit of DNaseI (New England Biolabs) and incubated at $37^{\circ} \mathrm{C}$ for 30 min twice. Then $4 \mu \mathrm{g}$ of DNase-treated RNA was reverse-transcribed by using M-MLV reverse transcriptase (Invitrogen). The reverse transcription conditions were $25^{\circ} \mathrm{C}$ for $10 \mathrm{~min}$, $37^{\circ} \mathrm{C}$ for $60 \mathrm{~min}$, and $70^{\circ} \mathrm{C}$ for $15 \mathrm{~min}$. Finally, the reverse-transcribed samples were treated with RNase (Invitrogen) at $37^{\circ} \mathrm{C}$ for $20 \mathrm{~min}$.

The rps13 genes were amplified from genomic DNA and cDNA by polymerase chain reaction (PCR) using genespecific primers (see Additional file 6). The PCR was performed in a reaction mixture $(10 \mu \mathrm{l})$ consisting of $4.88 \mu \mathrm{l}$ of $\mathrm{ddH}_{2} \mathrm{O}, 1 \mu \mathrm{l}$ of genomic DNA/cDNA solution, $1 \mu \mathrm{l}$ of PCR buffer, $1 \mu \mathrm{l}$ of $2.5 \mathrm{mM} \mathrm{MgCl}_{2}$ solution, $1 \mu \mathrm{l}$ of $0.2 \mathrm{mM}$ dNTPs, $0.5 \mu \mathrm{l}$ of $0.4 \mu \mathrm{M}$ each primer, and 0.12 units of Taq DNA Polymerase (Sigma). The PCR conditions were $96^{\circ} \mathrm{C}$ for $4 \mathrm{~min}$, and 30 cycles of $96^{\circ} \mathrm{C}$ for $40 \mathrm{~s}, 60^{\circ} \mathrm{C}$ for $40 \mathrm{~s}, 72^{\circ} \mathrm{C}$ for $1 \mathrm{~min}$, and $72^{\circ} \mathrm{C}$ for $10 \mathrm{~min}$. The PCR products were run on a $1.5 \%$ agarose gel and extracted from the gel using QIAquick Gel Extraction Kit (Qiagen). PCR products amplified from genomic DNA and cDNA were sequenced directly. The sequencing was performed in a reaction mixture containing $0.4 \mu \mathrm{l}$ of ABI BigDye Version 3.1 (Applied Biosystems), $3.6 \mu \mathrm{l}$ of BigDye buffer, $5.5 \mu \mathrm{l}$ of $50 \mathrm{ng}$ template, and $0.5 \mu \mathrm{l}$ of $0.4 \mu \mathrm{M}$ forward or reverse primer. The sequencing reaction was carried out with the following program: $1 \mathrm{~min}$ at $96^{\circ} \mathrm{C}$, and 25 cycle of $10 \mathrm{~s}$ at $96^{\circ} \mathrm{C}, 5 \mathrm{~s}$ at $50^{\circ} \mathrm{C}$, and $4 \mathrm{~min}$ at $60^{\circ} \mathrm{C}$. The sequencing products were run on an ABI 377 DNA Sequencer (Applied Biosystems) at the UBC Centre for Plant Research, or on an ABI 3730 Sequencer at the Nucleic Acids Protein Service unit at UBC. The GenBank accession number for $\mathrm{mt}$ rps13 in Malus, including information about RNA editing sites, is [GenBank: EU084692].

\section{Real-time qRT-PCR}

Quantitative real-time RT-PCR was performed with a BioRad iQ5 system using SYBR green master mix (BioRad) following the manufacturer's instructions, except that $25 \mu$ l total reaction volumes were used. The PCR conditions were $96^{\circ} \mathrm{C}$ for $3 \mathrm{~min}$, and then 35 cycles of $96^{\circ} \mathrm{C}$ for $10 \mathrm{~s}, 58^{\circ} \mathrm{C}$ for $30 \mathrm{~s}$, and $72^{\circ} \mathrm{C}$ for $30 \mathrm{~s}$. Gene-specific primers are listed in Additional file 6. For each sample, two technical replicates were performed. Reactions for a standard curve were run with each set of experimental reactions. After the completion of PCR, the melting curves were analyzed to distinguish the true product from artifacts such as primer dimers. The iQ5 software and Microsoft Excel were used for data analysis. Normalization was done using the actin gene ACT2. GenBank accession numbers for sequences used to design primers are: Malus ACT2: CN903171, CN902302, and N917499; Malus cob: $\underline{\mathrm{CN} 872477}, \underline{\mathrm{CN} 856986}, \underline{\mathrm{CN856316}} ;$ Malus rps10: CV882925. 


\section{Abbreviations}

BEB, Bayes Empirical Bayes analysis; EST, expressed sequence tag; LRT, likelihood ratio test; $M L$, maximum likelihood; NCBI, National Center for Biotechnology Information; qRT-PCR, quantitative real-time polymerase chain reaction; RT-PCR, reverse transcription-polymerase chain reaction

\section{Authors' contributions}

SLL planned and carried out the experiments and analyses, and wrote the manuscript. KA conceived the study, helped with the experimental design, and wrote the manuscript. Both authors read and approved of the final manuscript.

\section{Additional material}

\section{Additional file 1}

$M t$ rps13 distribution among rosids. The figure shows losses of $m t$ rps13 among rosids in a phylogenetic context, and the inferred timing of numit rps13 formation by gene duplication.

Click here for file

[http://www.biomedcentral.com/content/supplementary/14712148-8-25-S1.PDF]

\section{Additional file 2}

Pairwise $K_{a}$ and $K_{s}$ analyses. The table shows the results of $K_{a}$ analysis and $K_{s}$ analysis for numit rps13 and nucp rps13 in seven rosid species. Click here for file

[http://www.biomedcentral.com/content/supplementary/1471-

2148-8-25-S2.PDF]

\section{Additional file 3}

Microarray data legend. The table lists the organs and developmental stages from Arabidopsis thaliana for which microarray data were analyzed.

Click here for file

[http://www.biomedcentral.com/content/supplementary/14712148-8-25-S3.PDF]

\section{Additional file 4}

RNA editing of $m t$ rps13 in Malus compared with other flowering plants. The figure shows an alignment of $m t \mathrm{rps} 13$ from several land plants, indicating the positions of RNA editing sites in Malus, and a list of $m t$ rps 13 RNA editing sites from several angiosperms.

Click here for file

[http://www.biomedcentral.com/content/supplementary/14712148-8-25-S4.PDF]

\section{Additional file 5}

Sequence alignment. The figure shows an alignment of numit rps13, nucp rps13, and cDNAs of mt rps13 for taxa analyzed in this study. The targeting sequences at the $5^{\prime}$ end of the numit rps13 and nucp rps13 genes do not align with each other and were excluded from $K_{a} / K_{s}$ analysis. Click here for file

[http://www.biomedcentral.com/content/supplementary/14712148-8-25-S5.PDF

\section{Additional file 6}

RT-PCR primers. The table lists the primers used for RT-PCR and qRTPCR experiments.

Click here for file

[http://www.biomedcentral.com/content/supplementary/14712148-8-25-S6.PDF]

\section{Acknowledgements}

We thank Nolan Kane and Michael Barker for advice on the $\mathrm{K}_{\mathrm{a}} / \mathrm{K}_{\mathrm{s}}$ analysis and LRTs, two anonymous reviewers for helpful comments on an earlier version of the manuscript, and the UBC Botanical Garden for providing tissue from their apple trees. This study was funded by a grant from the National Science and Engineering Research Council of Canada, by start-up funds from the Faculty of Land and Food Systems at the University of British Columbia, and by infrastructure funds from the Canadian Foundation for Innovation.

\section{References}

I. Wagner A: Selection after gene duplication: a view from the genome. Genome Biol 2002, 3:1012.1-1012.3.

2. Zhang J: Evolution by gene duplication: an update. Trends Ecol Evol 2003, I 8:292-298.

3. Li WH, Yang J, Gu X: Expression divergence between duplicate genes. Trends Genet 2005, 2 1:602-607.

4. Ohno S: Evolution by gene duplication. New York, Springer; 1970.

5. Force A, Lynch M, Pickett FB, Amores A, Yan Y, Postlethwait J: Preservation of duplicate genes by complementary, degenerative mutations. Genetics 1999, I5 I:I531-1545.

6. Lynch M, Force A: The probability of duplicate gene preservation by subfunctionalization. Genetics 2000, I 54:459-473.

7. Moore RC, Purugganan MD: The early stages of duplicate gene evolution. Proc Natl Acad Sci USA 2003, I 00:I 5682-I 5687.

8. Lawton-Rauh A: Evolutionary dynamics of duplicated genes in plants. Mol Phylogenet Evol 2003, 29:396-409.

9. Moore RC, Purugganan MD: The evolutionary dynamics of plant duplicate genes. Curr Opin Plant Biol 2005, 8: I 22- I 28.

10. Adams KL, Wendel JF: Polyploidy and genome evolution in plants. Curr Opinion Plant Biol 2005, 8: |35-|4|.

II. Adams KL, Daley DO, Whelan J, Palmer JD: Genes for two mitochondrial ribosomal proteins in flowering plants are derived from their chloroplast or cytosolic counterparts. Plant Cell 2002, 14:931-943.

12. Mollier P, Holffmann B, Debast C, Small I: The gene encoding Arabidopsis thaliana mitochondrial ribosomal protein $S 13$ is a recent duplication of the gene encoding plastid SI3. Curr Genet 2002, 40:405-409.

13. Adams KL, Qiu YL, Stoutemyer M, Palmer JD: Punctuated evolution of mitochondrial gene content: high and variable rates of mitochondrial gene Loss and transfer to the nucleus during angiosperm evolution. Proc Natl Acad Sci USA 2002, 99:9905-9912.

14. Claros MG, Vincens P: Computational method to predict mitochondrially imported proteins and their targeting sequences. Eur J Biochem 1996, 24 I:779-786.

15. Emanuelsson O, Nielsen H, Brunak S, von Heijne G: Predicting subcellular localization of proteins based on their $\mathbf{N}$-terminal amino acid sequence. J Mol Biol 2000, 300:1005-1016.

16. Small I, Peeters N, Legeai F, Lurin C: Predotar: A tool for rapidly screening proteomes for $\mathbf{N}$-terminal targeting sequences. Proteomics 2004, 4: I58I-I590.

17. Bannai H, Tamada Y, Maruyama O, Nakai K, Miyano S: Extensive feature detection of $\mathbf{N}$-terminal protein sorting signals. Bioinformatics 2002, I 8:298-305.

18. Soltis DE, Soltis PE, Endress PK, Chase MW: Phylogeny and Evolution of Angiosperms. Sunderland, Sinauer Associates, Inc., USA; 2005:370. 
19. Jansen RK, Kaittanis C, Saski C, Lee SB, Tomkins J, Alverson AJ, Daniell H: Phylogenetic analyses of Vitis (Vitaceae) based on complete chloroplast genome sequences: effects of taxon sampling and phylogenetic methods on resolving relationships among rosids. BMC Evol Biol 2006, 6:32.

20. Jaillon O, Aury JM, Noel B, Policriti A, Clepet C, Casagrande A Choisne N, Aubourg S, Vitulo N, Jubin C, Vezzi A, Legeai F, Hugueney P, Dasilva C, Horner D, Mica E, Jublot D, Poulain J, Bruyere C, Billault A, Segurens B, Gouyvenoux M, Ugarte E, Cattonaro F, Anthouard V, Vico V, Fabbro CD, Alaux M, Gaspero GD, Dumas V, Felice N, Paillard S, Juman I, Moroldo M, Scalabrin S, Canaguier A, Clainche IL, Malacrida G, Durand E, Pesole G, Laucou V, Chatelet P, Merdinoglu $D$, Delledonne M, Pezzotti M, Lecharny A, Scarpelli C, Artiguenave F, Pe ME, Valle G, Morgante M, Caboche M, Adam-Blondon AF, Weissenbach J, Quetier F, Wincker P: The grapevine genome sequence suggests ancestral hexaploidization in major angiosperm phyla. Nature 2007, 449:463-467.

21. Kumar R, Drouaud J, Raynal M, Small I: Characterization of the nuclear gene encoding chloroplast ribosomal protein $\mathrm{SI3}$ from Arabidopsis thaliana. Curr Genet 1995, 28:346-352.

22. Swanson WJ, Nielson R, Yang Q: Pervasive adaptive evolution in mammalian fertilization protein. Mol Biol Evol 2003, 20:18-20.

23. Yang Z: PAML: a program package for phylogenetic analysis by maximum likelihood. Comput Appl Biosci 1997, 13:555-556.

24. Yang Z Swanson, W.J.: Codon-substitution models to detect adaptive evolution that account for heterogeneous selective pressures among site clesses. Mol Biol Evol 2002, 19:49-57.

25. Yang Z: PAML 4: Phylogenetic analysis by maximum likelihood. Mol Biol Evol 2007, 24:|586-I59|.

26. Yang Z, Nielson R: Codon-substitution models for detecting molecular adaptation at individual sites along specific lineages. Mol Biol Evol 2002, 19:908-917.

27. Carter AP, Clemons WM, Broderson DE, Morgan-Warren RJ, Wimberly BT, Ramakrishnan V: Functional insights from the structure of the $30 \mathrm{~S}$ ribosomal subunit and its interactions with antibiotics. Nature 2000, 407:340-348.

28. Yusupov MM, Yusupova GZ, Baucom A, Lieberman K, Earnest TN, Cate JHD, Noller HF: Crystal structure of the ribosome at 5.5A resolusion. Science 200I, 292:883-896.

29. Broderson DE, Clemons Jr. WM, Carter AP, Wimberly BT, Ramakrishnan V: Crystal structure of the $30 \mathrm{~S}$ ribosomal subunit from Thermus thermophilus: structure of the proteins and their interactions with I6S RNA. J Mol Biol 2002, 3 I 6:725-768.

30. Schmid M, Davison TS, Henz SR, Pape UJ, Demar M, Vingron M, Scholkopf B, Weigel D, Lohmann JU: A gene expression map of Arabidopsis thaliana development. Nature Genet 2005, 37:50I-506.

31. Bonen L, Calixte S: Comparative analysis of bacterial-origin genes for plant mitochondrial ribosomal proteins. Mol Biol Evol 2006, 23:70I-7II2.

32. Newcomb RD, Crowhurst RN, Gleave AP, Rikkerink EH, Allan AC Beuning LL, Bowen JH, Gera E, Jamieson KR, Janssen BJ, Laing WA, McArtney S, Nain B, Ross GS, Snowden KC, Souleyre EJ, Walton EF, Yauk YK: Analyses of expressed sequence tags from apple. Plant Physiol 2006, 141: | 47-166.

33. Shikanai T: RNA editing in plant organelles: machinery, physiological function and evolution. Cell Mol Life Sci 2006, 63:698-708.

34. Conant GC, Wagner A: Asymmetric sequence divergence of duplicate genes. Genome Res 2003, 13:2052-2058.

35. Byrne KP, Wolfe $\mathrm{KH}$ : Consistent patterns of rate asymmetry and gene loss indicate widespread neofunctionalization of yeat genes after whole-genome duplication. Genetics 2007, 175: $134 \mid-1350$

36. Thomas JH: Adaptive evolution in two large families of ubiquitin-ligase adapters in nematodes and plant. Genome Res 2006 16:1017-1030.

37. Sun $X, C a o Y$, Wang S: Point mutations with positive selection were a major force during the evolution of a receptor-kinase resistance gene family of rice. Plant Physiol 2006, I 40:998-1008.

38. Johnson DA, Thomas MA: The monosaccharide transporter gene family in Arabidopsis and rice: A history of duplications, adaptive Evolution, andfunctional divergence. Mol Biol Evol 2007, 24:2412-2423.

39. Hernandez-Hernandez T, Martinez-Castilla LP, Alvarez-Buylla ER Functional diversification of B MADS-box homeotic regula- tors of flower development: adaptive evolution in proteinprotein interaction domains after major gene duplication events. Mol Biol Evol 2007, 24:465-48I

40. Gu Z, Nicolae D, Lu HH, Li WH: Rapid divergence in expression between duplicate genes inferred from microarray data. Trends Genet 2002, 18:609-6I3.

4I. Gu X, Zhang Z, Huang W: Rapid evolution of expression and regulatory divergences after yeast gene duplication. Proc Nat Acad Sci USA 2005, I 8:707-7I2.

42. Chung WY, Albert R, Albert I, Nekrutenko A, Makova KD: Rapid and asymmetric divergence of duplicate genes in the human gene coexpression network. BMC Bioinformatics 2006, 27:7:46.

43. Blanc $\mathrm{G}$, Wolfe $\mathrm{KH}$ : Functional divergence of duplicated genes formed by polyploidy during Arabidopsis evolution. Plant Cell 2004, 16:1679-1691.

44. Casneuf T, De Bodt S, Raes J, Maere S, Van de Peer Y: Nonrandom divergence of gene expression following gene and genome duplications in the flowering plant Arabidopsis thaliana. Genome Biol 2006, 7:RI3.

45. Ganko EW, Meyers BC, Vision T]: Divergence in Expression between Duplicated Genes in Arabidopsis. Mol Biol Evol 2007, 24:2298-2309.

46. Adams KL, Palmer JD: Evolution of mitochondrial gene content: gene loss and transfer to the nucleus. Mol Phylogenet Evol 2003, 29:380-395

47. Bittner-Eddy P, Monroy AF, Brambl R: Expression of mitochondrial genes in the germinating conidia of Neurospora crassa. J Mol Biol 1994, 235:88I-897.

48. Adams KL, Song K, Roessler PG, Nugent JM, Doyle JL, Doyle JJ, Palmer JD: Intracellular gene transfer in action: Dual transcription and multiple silencings of nuclear and mitochondrial cox2 genes in legumes. Proc Natl Acad Sci USA 1999, 96:13863-13868

49. Sandoval P, Leon G, Gomez I, Carmona R, Figueroa P, Holuigue L, Araya A, Jordana X: Transfer of RPSI4 and RPL5 from the mitochondrion to the nucleus in grasses. Gene 2004, 324:139-147.

50. Choi C, Liu Z, Adams KL: Evolutionary transfers of mitochondrial genes to the nucleus in the Populus lineage and coexpression of nuclear and mitochondrial Sdh4 genes. New Phytol 2006, 172:429-439.

51. Bininda-Emonds ORP: transAlign: using amino acids to facilitate the multiple alignment of protein-coding DNA sequences. BMC Bioinformatics 2005, 6:156.

52. Hall TA: BioEdit: a user-friendly biological sequence alignment editor and analysis program for Windows 95/98/NT. Nucleic Acids Symp Ser 1999, 41:95-98.

53. Keane TM, Naughton TJ, Mclnerney JO: MultiPhyl: A highthroughput phylogenomics webserver using distributed computing. Nucleic Acids Res 2007, 35:W33-W37.

54. The statistical package R. [http://www.r-project.org/]

55. Yang Z, Nielson R, Goldman N, Pedersen AMK: Codon-substitution models for heterogeneous selection pressure at amino acid sites. Genetics 2000, I55:43I-449.

56. Friedman R, Hughes AL: Likelihood-ratio tests for positive selection of human and mouse duplicate genes reveal nonconservative and anomalous properties of widely used methods. Mol Phylogenet Evol 2006, 42:388-393.

57. Kapralov MV, Filatov DA: Widespread positive selection in the photosynthetic Rubisco enzyme. BMC Evol Biol 2007, 7:73.

58. Yang Z, Wong WS, Nielsen R: Bayes empirical bayes inference of amino acid sites under positive selection. Mol Biol Evol 2005, 22:1107-1118.

59. Schwede T, Kopp J, Gues N, M.C. P: SWISS-MODEL: an automated protein homology-modeling server. Nucleic Acids Res 2003, $31: 3381-3385$.

60. Mitra K, Schaffitzel C, Fabiola F, Chapman MS, Ban N, Frank J: Elongation arrest by SecM via a cascade of ribosomal RNA rearrangements. Mol Cell 2006, 22:533-543.

61. RCSB Protein Data Bank. [http://www.rcsb.org/pdb]

62. TAIR: The Arabidopsis Information Resource. www.arabidopsis.org/]

63. Wu Z, Irizarry RA, Gentleman R, Murillo FM, Spencer F: A model based background adjustment for oligonucleotide expression arrays. J Am Stat Assoc 2004, 99:909-917. 
64. Adams KL, Cronn R, Percifield R, Wendel JF: Genes duplicated by polyploidy show unequal contributions to the transcriptome and organ-specific reciprocal silencing. Proc Natl Acad Sci USA 2003, 100:4649-4654.

Publish with Bio Med Central and every scientist can read your work free of charge

"BioMed Central will be the most significant development for disseminating the results of biomedical research in our lifetime. " Sir Paul Nurse, Cancer Research UK

Your research papers will be:

- available free of charge to the entire biomedical community

- peer reviewed and published immediately upon acceptance

- cited in PubMed and archived on PubMed Central

- yours - you keep the copyright

Submit your manuscript here:

http://www.biomedcentral.com/info/publishing_adv.asp
BioMedcentral 